\begin{tabular}{|l|l|l||}
\hline \multicolumn{2}{|c|}{ PublisherInfo } \\
\hline \hline PublisherName & $:$ & BioMed Central \\
\hline \hline PublisherLocation & $:$ & London \\
\hline \hline PublisherImprintName & $:$ & BioMed Central \\
\hline \hline
\end{tabular}

\title{
Autoantigenic B cells and their role in lymphomagenesis in Sjogren's disease
}

\begin{tabular}{||l|l|l||}
\hline \multicolumn{2}{|c||}{ ArticleInfo } \\
\hline \hline ArticleID & $:$ & 188 \\
\hline \hline ArticleDOI & $:$ & $10.1186 /$ ar-2000-66803 \\
\hline \hline ArticleCitationID & $:$ & 66803 \\
\hline \hline ArticleSequenceNumber & $:$ & 145 \\
\hline \hline ArticleCategory & $:$ & Paper Report \\
\hline ArticleFirstPage & $:$ & 1 \\
\hline \hline ArticleLastPage & $:$ & 3 \\
\hline \hline & & RegistrationDate : 2000-5-2 \\
ArticleHistory & $:$ & OnlineDate $: 2000-5-2$ \\
\hline \hline ArticleCopyright & $:$ & Current Science Ltd2000 \\
\hline \hline ArticleGrants & $:$ & \\
\hline \hline ArticleContext & $:$ & 130753311 \\
\hline \hline
\end{tabular}


Aff1 Charite University Hospital, Berlin

\section{Keywords}

B cells, hypermutation, immunglobulin V genes, Sjogren's syndrome

\section{Context}

Primary SS is an organ-specific autoimmune disease with a characteristic lymphocytic infiltration of the salivary and lacrimal glands. A 44-fold increased risk for the development of lymphomas preferentially occurring at extranodal sites, in particular in the major salivary glands, has been documented.

The transition from early clusters of lymphocytes, often organized in structures resembling germinal centers, to lymphoma is still not well documented on the molecular level. It is not clear whether autoantibody-producing cells interfere with the development of these lymphomas. To investigate whether the development of salivary gland lymphomas is intimately linked to autoantibody-producing cells in primary SS.

\section{Significant findings}

In both cases, single clonal bands of the VH and V? PCR products were detected. One lymphoma expressed a VH gene rearrangement employing V3-7 (V3-7*01, DP54), D21-9 and JH3?. The respective L chain consisted of the V?III gene Humkv328h5 (L2, DPK21) rearranged to J?1. The other lymphoma expressed a mutated copy of the VH6 gene V6-1*02 (DP74) rearranged to DK1 and JH5a. The VL gene rearrangement used the V?III gene $\mathrm{Vg}$ (L6). The analysis of the somatic mutations identified mutated rearrangements with the exception of one L chain. Most of the mutations were seen in all the clonally related sequences, while other, rare mutations were only present in the clonal OPP V sequences (in the individual from whom the $\mathrm{V}$ sequences were derived). There was no clustering of replacement mutations in the complementarity-determining regions as the authors would have expected. After expressing these $\mathrm{V}$ rearrangements, the binding capabilities of the expressed IgM chain were tested against a panel of autoantigens. Both IgMs had significant RF activity in ELISA but apparently did not react with any other antigen tested. 


\section{Comments}

This study characterized $\mathrm{V}$ gene rearrangements obtained from lymphomas of two patients with Sjogren's syndrome (SS) and showed that both the reexpressed IgM? products had rheumatoid factor (RF) specificity. These data document that autoantigenic drive, especially IgG as autoantigen, might be responsible at least in part for the transformation of these B cells in SS. The authors discuss the importance of ectopic germinal centers in detail; however, they do not mention the methodological bias inherent when using VH and V?-specific primers for amplifying from bulk cDNA. This bias might have influenced the data in terms of $\mathrm{V}$ gene detection, the overall mutational pattern and the distribution of mutations.

\section{Methods}

Lymphoma cells were obtained from two patients. The expressed V genes were amplified by PCR from biopsy specimens using specific primers for rearranged? and ? chains at the cDNA level, sequenced, and the heavy and ? chain gene rearrangements were subcloned into eukaryotic expression vectors. Both constructs were transfected into P3X63-Ag8.653 cells by electroporation to obtain two monoclonal cell lines. The secreted IgM? chains were tested by ELISA and immunofluorescence against a panel of antigens (human IgG, actin, thyroglobulin, myoglobin, and DNA) implicated in SS.

\section{References}

1. Thierry M, Weber JC, Levallois H, Labouret N, Soley A, Koenig S, Korganow AS, Pasquali JL: Salivary gland lymphomas in patients with Sjogrens's Syndrome may frequently develop from rheumatoid factor B cells . Arthritis Rheum. 2000, 43: 908-916.

This PDF file was created after publication. 